\title{
Immunocytochemical and Electrophysiological Differentiation of Rat Cerebellar Granule Cells in Explant Cultures
}

\author{
Philip E. Hockberger, Hsiu-Yu Tseng, and John A. Connor \\ Department of Molecular Biophysics, AT\&T Bell Laboratories, Murray Hill, New Jersey 07974
}

\begin{abstract}
We have used a combination of immunocytochemical and electrophysiological measurements to monitor the differentiation of cerebellar granule cells in vitro. We present immunocytochemical evidence showing that several characteristic features of developing rat cerebellar tissue were retained in postnatal explant cultures. Most notably the cultures expressed radiating GFAP-positive (Bergmann) glia processes, proliferating NSE-negative neuroblasts, and migrating NSE-positive granule cells. The latter were subdivided into 3 developmental stages-i.e., immature, intermediate, and mature granule cells, based upon cell differences in location from the explant, intensity of NSE staining, excitability, and the amplitude of voltage-dependent conductances. Immature cells were identifiable during the first week in culture and were located up to $140 \mu \mathrm{m}$ from the explant. These cells stained lightly for NSE and displayed conductances of insufficient magnitude to generate action potentials. Intermediate cells were present after 1-2 weeks in culture and were located up to $500 \mu \mathrm{m}$ from the explant. These cells were also NSE positive and were characterized by the presence of soma action potentials. Intermediate cells displayed 3 large voltage-dependent conductances: a transient, TTX-sensitive inward current; a delayed, TEA-sensitive outward current; and a transient, 4AP-sensitive outward current. Mature cells were present after 1 month in culture and, like intermediate cells, were no more than $500 \mu \mathrm{m}$ from the explant. However, mature cells stained more intensely for NSE, and the somata of these cells were devoid of voltage-dependent conductances (although axonal currents were usually present). These results indicate that granule cells undergo a stereotypic sequence of differentiation in postnatal explant cultures. These stages may correspond to developmental changes in granule cells during migration into the (internal) granular cell layer in vivo.
\end{abstract}

Cerebellar granule cells comprise the largest population of identifiable neurons in the vertebrate brain. The number of granule cells has been estimated to be equivalent to all other nerve cells combined in some mammals and roughly equivalent to the total number of cerebral neurons in humans (Ito, 1984). Despite their

\footnotetext{
Received June 3, 1986; revised Oct. 16, 1986; accepted Oct. 30, 1986.

That part of this work not sponsored by AT\&T Bell Laboratories was supported by a grant from the Air Force Office of Scientific Research under Contract F49620. We would like to thank $H$. Chiel and D. Kleinfeld for helpful discussion and suggestions regarding the manuscript.

Correspondence should be addressed to Philip E. Hockberger, Department of Molecular Biophysics, 1C-456, AT\&T Bell Laboratories, 600 Mountain Ave., Murray Hill, NJ 079\%.

Copyright (C) 1987 Society for Neuroscience $0270-6474 / 87 / 051370-14 \$ 02.00 / 0$
}

impressive numbers, not much is known about the electrophysiological and biophysical properties of either developing or mature granule cells. The very small size of granule cells (soma diameter, 4-6 $\mu \mathrm{m}$ ) has made it virtually impossible to record intracellular signals using conventional microelectrode techniques. With the development of whole-cell patch recording (Hamill et al., 1981; Fenwick et al., 1982a) it is now possible not only to record intracellularly from such cells, but also to analyze voltage-dependent conductances.

Tissue culture methods have also facilitated small-cell recording by allowing greater visibility of and accessibility to individual cells, as well as affording control over the cellular environment. Cerebellar granule cells from postnatal rodents have been grown in culture using either serum-supplemented media (Lasher and Zagon, 1972; Messer, 1977) or completely defined medium (Messer et al., 1981; Fischer, 1982; Kingsbury et al., 1985). Dissociated cerebellar cultures prepared from 1- to 2-week-old rats yield a relatively uniform population of granule cells that exhibited depolarization-induced release of putative amino acid transmitters (Drejer ct al., 1983; Levi et al., 1984), transmitter-induced uptake of ${ }^{45} \mathrm{Ca}^{2+}$ (Wroblewski et al., 1985), transmitter-activated ion channels (Cull-Candy and Ogden, 1985), and transmitter modulation of second messenger levels (Xu and Wojcik, 1985). Differences in growth properties between normal and mutant granule cells have also been reported in vitro (Messer and Smith, 1977; Messer, 1978; Willinger and Margolis, 1985). However, until now there has been no analysis of electrical excitability in granule cells under these conditions nor any evidence that similar events occur in situ.

In this report we demonstrate that explant cultures of postnatal rat cerebellum offer conditions for studying several stages of granule cell differentiation in vitro. Using whole-cell patch recording and immunocytochemical staining, we show that granule cells develop electrical excitability and immunoreactivity in vitro during a period that may correspond to their migration into the (internal) granular cell layer in vivo. In the following paper (Connor et al., 1987), we report the use of whole-cell recording and fluorescence imaging of granule cells loaded with fura-2 to demonstrate the development of transmitter-induced changes in membrane conductance and intracellular free $\mathrm{Ca}^{2+}$, respectively. Preliminary descriptions of these findings have been previously reported (Hockberger and Connor, 1985; Hockberger et al., 1986).

\section{Materials and Methods}

Tissue cultures. Explant slide cultures of cerebella were prepared from Sprague-Dawley rats between postnatal days 3 (P3) and 5 (P5). For some experiments, late embryonic (E20-E22) specimens were used. Cerebella from littermates of the same age were isolated, pooled, and 
minced into $0.3-1 \mathrm{~mm}$ pieces while bathed in an antibiotic-isotonic buffer solution ( $137 \mathrm{~mm} \mathrm{NaCl}, 5.4 \mathrm{~mm} \mathrm{KCl}, 0.2 \mathrm{~mm} \mathrm{Na} \mathrm{mPO}_{4}, 0.2 \mathrm{~mm}$ $\mathrm{KH}_{2} \mathrm{PO}_{4}, 5.5 \mathrm{~mm}$ glucose, $5.9 \mathrm{~mm}$ sucrose, $0.02 \mathrm{~mm}$ phenol red, adjusted to $\mathrm{pII} 7.2$, and containing $250 \mu \mathrm{g} /$ liter fungizone, $100 \mathrm{mg} / \mathrm{liter}$ streptomycin, $10^{5}$ units/liter penicillin) at $4^{\circ} \mathrm{C}$. Pieces were transferred to poly(D-lysine)-coated glass coverslips (Fisher, no. 1, $18 \mathrm{~mm}$ ) stored in 12 well culture dishes (Belco Glass, Inc., Vineland, NJ) at a density of 10-20 pieces/coverslip.

Cultures were maintained for up to 5 weeks in a standard culture medium containing Minimal Essential Medium with Earle's salts but without glutamine (MEM) (Gibco, Grand Island, NY). Standard medium also contained additional glucose (total, $6 \mathrm{~g} /$ liter), $\mathrm{NaHCO}_{3}$ (total, $3.7 \mathrm{~g} /$ liter $), 2 \mathrm{~mm}$ glutamine, heat-inactivated horse serum $(10 \% \mathrm{vol} /$ vol, Gibco), and N3 medium supplement (Romijn et al., 1982). For some experiments, the medium was supplemented with $60 \mu \mathrm{M} 5^{\prime}$-fluoro$2^{\prime}$-deoxyuridine (FUDR; Sigma, St. Louis, MO), $10^{-4} \mathrm{M}$ cytosine arabinofuranoside (Sigma), $20 \mathrm{~mm} \mathrm{KCl}$, or $10^{-4}$ м kainic acid (Sigma). Alternatively, a completely defined medium was employed as described elsewhere (Ahmed et al., 1983). In all cases, culture medium was replaced initially after $3-4 \mathrm{~d}$ and thereafter replenished 3 times a week. Cultures were incubated at $37^{\circ} \mathrm{C}$ in a humidified environment of $90 \%$ air $/ 10 \% \mathrm{CO}_{2}$ (NAPCO, model 4600 , Portland, OR).

Immunocytochemistry. Peroxidase-antiperoxidase (PAP) staining for glia fibrillary acidic protein (GFAP) or neuron-specific enolase (NSE) was performed using polyclonal antisera and PAP complex supplied by DAKO Corp. (Santa Barbara, CA). Immunoperoxidase staining of cells was performed at room temperature, unless otherwise indicated. Coverslips were treated in the following sequence: (1) washed briefly in KrebsHEPES saline, fixed in Bouin's fluid for $1 \mathrm{hr}$, and then washed for 15 min in $50 \mathrm{~mm}$ Tris $\mathrm{HCl}$ buffer (pH 7.6); (2) placed $10 \mathrm{~min}$ in $3 \%$ hydrogen peroxide to remove endogenous peroxidase activity, followed by Tris buffer wash; (3) incubated $30 \mathrm{~min}$ in preimmune (or nonimmune) swine serum diluted $1: 20$ in $0.25 \%$ Triton X-100 in Tris buffer; (4) incubated 3-4 hr (or $24 \mathrm{hr}$ at $4^{\circ} \mathrm{C}$ ) in primary antibody rabbit serum (or nonimmune serum for control) diluted between 1:300 and 1:3000 in $0.5 \%$ Triton X-100 in Tris buffer; (5) washed $48 \mathrm{hr}$ in Tris at $4^{\circ} \mathrm{C}$; (6) incubated $30 \mathrm{~min}$ in secondary antibody swine serum diluted 1:100 in Tris; (7) washed 20 min in Tris; (8) incubated 30 min in PAP complex solution (Dako); (9) washed $20 \mathrm{~min}$ in Tris; (10) stained $40 \mathrm{~min}$ in 1.3 mM 3-amino-9-ethylcarbazole (AEC; stock dissolved in $N, N$-dimethylformamide) in $0.1 \mathrm{M}$ acetate buffer with $0.03 \% \mathrm{H}_{2} \mathrm{O}_{2} ;(11)$ counterstained with Mayer's hematoxylin (Sigma Chem. Co.) for $20 \mathrm{~min}$; (12) differentiated $5 \mathrm{~min}$ in $34 \mathrm{~mm}$ ammonia hydroxide; and (13) mounted on a slide using glycerol gelatin (Dako).

Positive control slides of brain were prepared from postnatal and adult Sprague-Dawlcy rats perfused several minutes with icc-cold PBS ( $\mathrm{pH}$ 7.6), followed by 10 min of cold Bouin's fixative. Fixed brains were removed and sectioned $(6 \mu \mathrm{m})$ with a cryostat at $-20^{\circ} \mathrm{C}$, and sections were attached to gelatin-coated slides. Immunoperoxidase staining of sections was performed as described above.

Electrophysiology. Intracellular recording and voltage-clamping were performed using whole-cell patch-recording techniques as described by Hamill et al. (1981). For recording we used a List EPC-7 patch-clamp amplifier (Medical Systems, Great Neck, NY). Recording electrodes (Rochester Products, Rochester, NY) were prepared on a 2-stage puller and polished with a microforge (Narishige, Tokyo, Japan) to obtain tip resistances of 1-2 M $\Omega$. The electrodes were filled with the following internal saline solution: $140 \mathrm{~mm} \mathrm{KAc}, 2 \mathrm{~mm} \mathrm{MgCl}_{2}, 1 \mathrm{~mm} \mathrm{CaCl}, 10$ mM EGTA, $10 \mathrm{~mm}$ HEPES buffer adjusted to pH 7.2. Cells were visualized with the aid of a Nikon inverted microscope (Diaphot), and recording electrodes were positioned using Narishige hydraulic micro- manipulators. Coverslips containing explants were mounted in a recording chamber on the microscope stage and superfused with the following modified Krebs (external) saline: $130 \mathrm{~mm} \mathrm{NaCl}, 5.4 \mathrm{mM} \mathrm{KCl}$, $1.8 \mathrm{~mm} \mathrm{CaCl}, 1 \mathrm{~mm} \mathrm{MgCl}, 25 \mathrm{~mm}$ glucose, $10 \mathrm{~mm}$ HEPES buffer adjusted to $\mathrm{pH}$ 7.2. All recordings were performed at room temperatures $\left(19-22^{\circ} \mathrm{C}\right)$, and cell survival under these conditions was typically greater than $3 \mathrm{hr}$.

Patch electrodes were left uncoated for the most part since we were interested in a general classification of currents rather than a close examination of their time courses. Current records are presented without subtraction of leakage or capacitative currents (except Fig. 10). We did utilize the capacitance compensation capabilities of the EPC-7 to reduce electrode and other stray capacitance prior to seal breakage. In most cases, series resistance compensation was not necessary since membrane currents were small, $<500 \mathrm{pA}$. Liquid junction potentials between internal and external salines were less than $2 \mathrm{mV}$ and were therefore ignored in our measurements.

\section{Results}

Immunocytochemical analysis of explant cultures

Radiating GFAP-positive processes extended out from each explant after 3-5 d in either serum-supplemented or defined medium (Fig. 1, top). The radial alignment was a general feature of each explant, and the processes typically passed over the top of other cells en route (Fig. 1, bottom). The GFAP staining and radial alignment suggested to us that these processes were most likely Bergmann glia fibers. Bergmann glia are fibrous astrocytes, which originate around birth from within the glia limitations overlying the cortical surface of the cerebellum (Ramon y Cajal, 1911; Del Cerro and Snider, 1972). During the first postnatal week in vivo, these astrocytes produce GFAP-positive fibers that infiltrate the cerebellum as rows of parallel processes extending perpendicular to the cortical surface (Bignami and Dahl, 1973, 1974). At present they are believed to be the only GFAP-staining processes in the cerebellar cortex (DeBlas, 1984). There are no satisfactory explanations for how this geometrical alignment is orchestrated, but it appears that the expression of GFAP, as well as parallel fiber orientation, can occur even in culture.

As with Bergmann fibers in vivo, the intensity of GFAP-positive staining in vitro increased throughout the first month. A primary antibody dilution of $1: 1500$, which was sufficient to show positive staining during the first week in culture (e.g., Fig. 1), produced overstaining a week later. In order to achieve a comparable intensity of staining after 3 weeks in culture, dilution was typically increased to $1: 3000$. With the higher concentrations of primary antibodies, many flat cells between explants were also GFAP positive. We have not attempted to identify these flat cell types, which displayed a variety of different shapes, but their numbers were greatly reduced in cultures exposed to $60 \mu \mathrm{M}$ FUDR, a mitotic inhibitor.

After several days in culture, we were also able to identify a second class of cells, which we have labeled granule cell neu-

Figure 1. GFAP immunostaining (antibody dilution, 1:1500) of P4 cerebellar explant fixed after 5 DIV and counterstained with hematoxylin (blue). Top, Processes can be seen radiating from the explant in all directions and appear to be GFAP positive (red). Calibration bar, $200 \mu \mathrm{m}$. Bottom, Higher magnification of inset shows the thick, GFAP-positive fibers surrounded by a large number of hematoxylin-stained nuclei of small, round cells (small arrow) migrating from the explant. Nuclei of GFAP-positive cells (large arrow) were larger and elliptical in shape. Calibration bar, $50 \mu \mathrm{m}$.

Figure 2. NSE immunostaining (antibody dilution, 1:1000) of P4 cerebellar explant fixed after 5 DIV and counterstained with hematoxylin (blue). Top, NSE-positive processes (red) radiated from the explant, similar to the GFAP-positive processes in Figure 1. Calibration bar, $200 \mu \mathrm{m}$. Bottom, Higher magnification of inset shows that the NSE-positive fibers were much thinner than the GFAP-positive fibers. Small, round NSE-positive cell bodies (smallest arrow) were differentiating granule cells. Small, round NSE-negative cell bodies (medium arrow) were neuroblasts. Large nuclei (large arrow) probably belong to cells producing the GFAP-positive fibers in Figure 1. Calibration bar, $50 \mu \mathrm{m}$. 

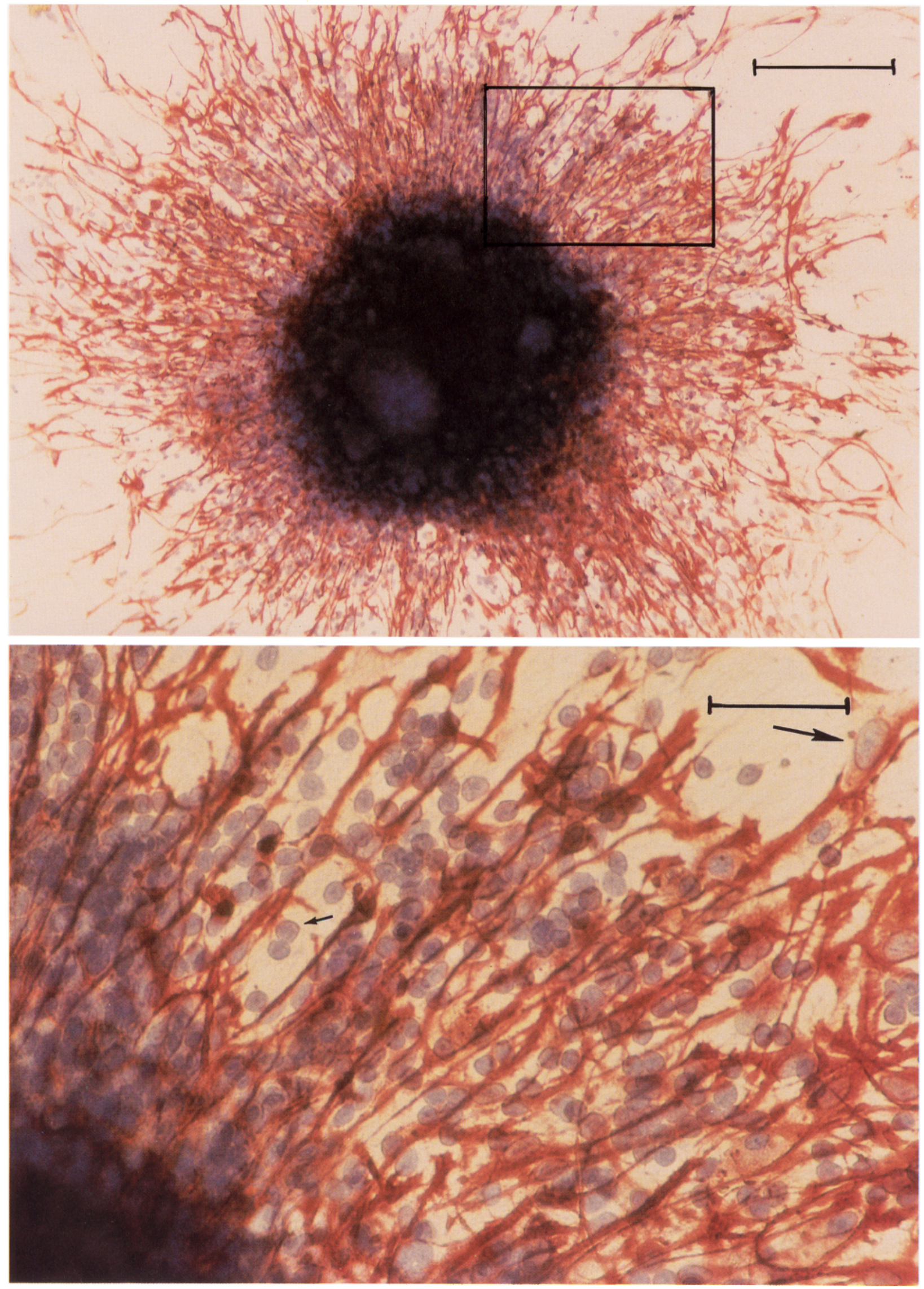

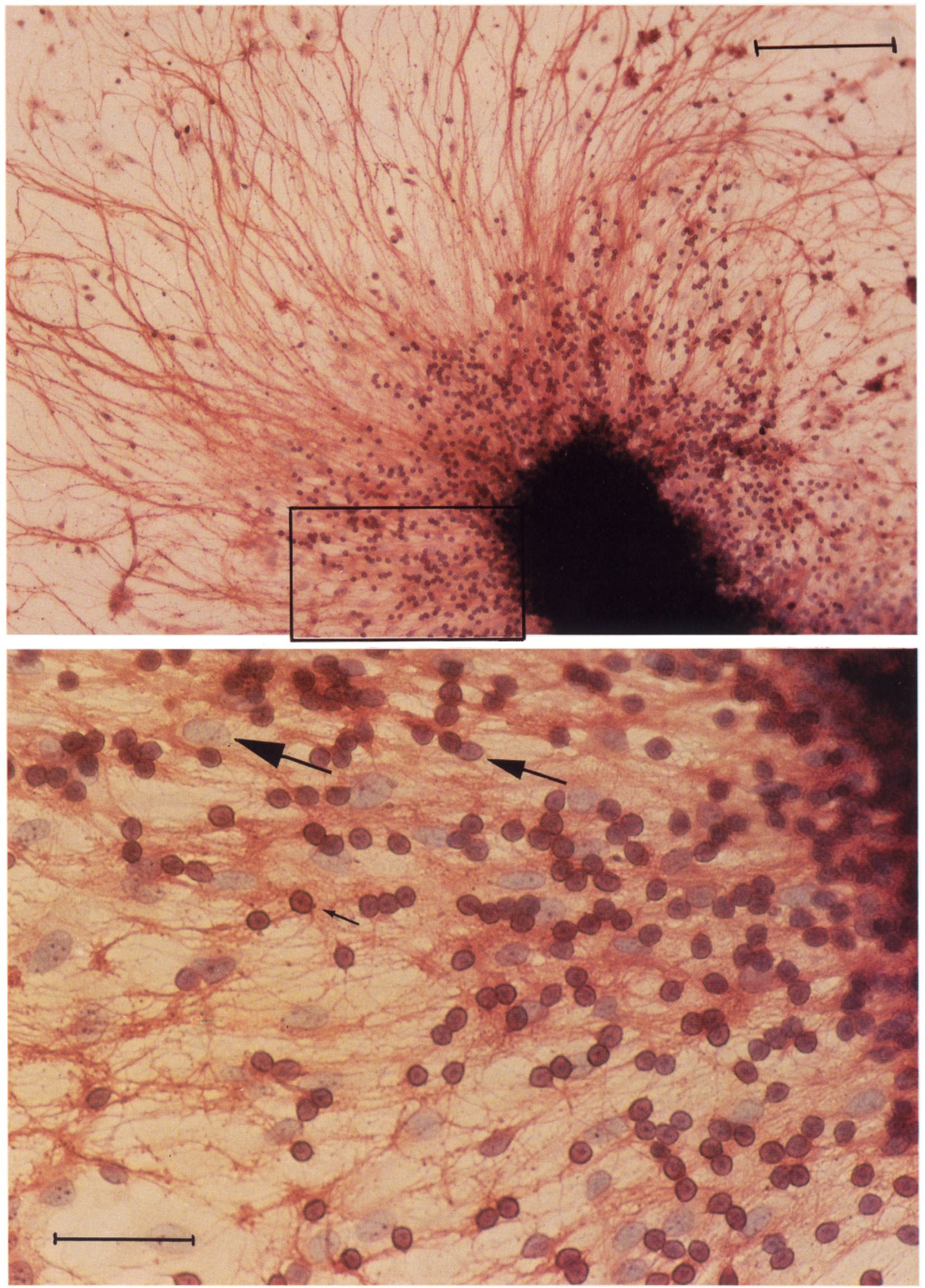


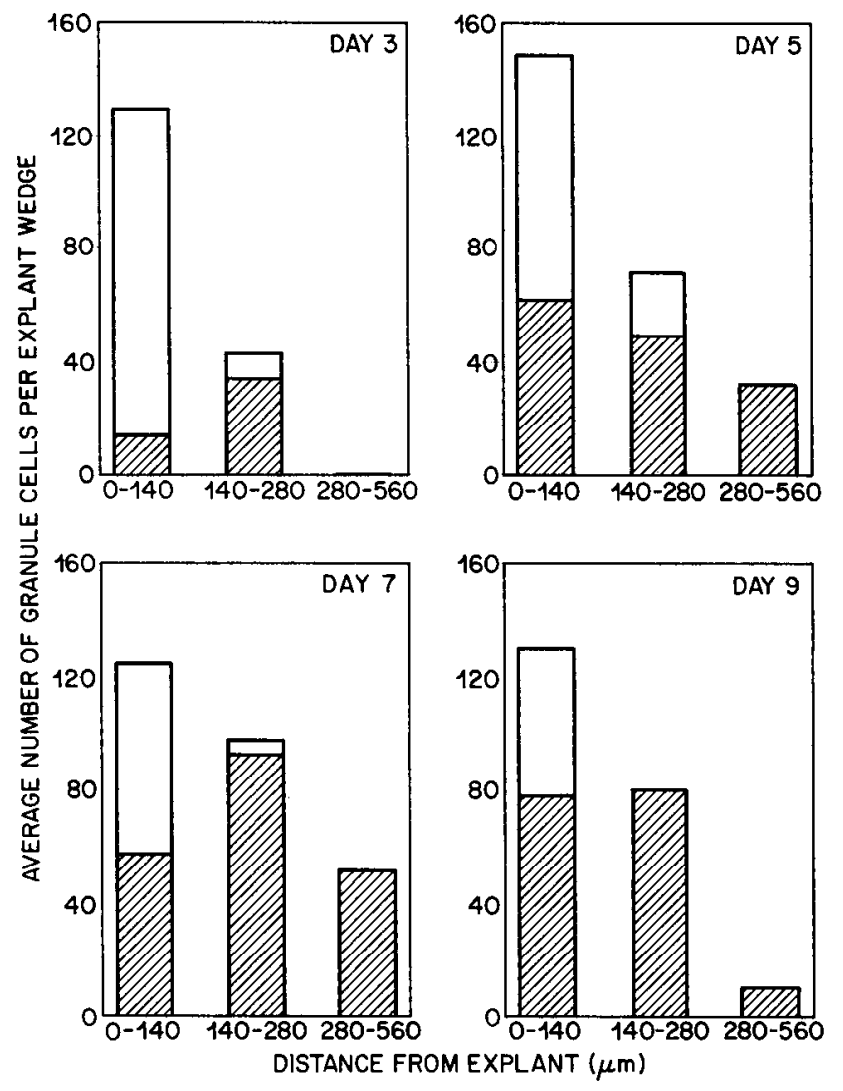

Figure 3. Graphic representation of NSE immunostaining results obtained from P4 explants after various culture times. The height of the bar graphs represents the average number of small cells in a representative section $(n=6)$ at various distances from the explant edge. The proportion exhibiting NSE staining is represented by the shaded area of the bar. The unshaded area represents neuroblasts, while the shaded arca indicates differentiating granulc cells. The granule cell population increased during the first week but decreased markedly beyond day 9 (data not shown). Cells that had migrated beyond $140 \mu \mathrm{m}$ showed a higher proportion of NSE staining at all stages examined.

roblasts. These cells were characterized by appearance (round and phase-bright) and were found adjacent to each explant. The cell bodies were roughly $8-10 \mu \mathrm{m}$ in diameter (nuclei approximately $5 \mu \mathrm{m}$ ) and extended 2 or 3 long processes. This cell type increased in number during the first week, an event which was eliminated by exposing the cultures to $10^{-4} \mathrm{M}$ cytosine arabinofuranoside. Seil et al. (1980) have shown that this treatment prevents the appearance of granule cells in explant cultures. At this stage of development the cells did not stain for either GFAP (Fig. $1 B$ ) or neuron-specific enolase (NSE) even at high antibody titer, i.e., 1:300 dilution. The latter is consistent with the observation that granule cell neuroblasts are NSE-negative in situ (Schmechel et al., 1978, 1980).

By the end of the first week in culture we observed that many phase-bright cells had migrated considerable distances from the explants (up to $500 \mu \mathrm{m}$ ). Although some of these cells resembled stellate, basket, Golgi, and Purkinje cells in various stages of differentiation, the overwhelming majority comprised a uniform group of smaller bipolar cells. We have identified these cells as migrating granule cells based upon a variety of criteria, including morphological characteristics (soma size, 6-8 $\mu \mathrm{m}$; soma shape, round or elliptical; processes, very thin and several hundred microns long; nuclear size, 4-6 $\mu \mathrm{m}$ ), birthdate (see Altman, 1972b), and survivability in culture medium containing kainic acid $\left(10^{-4} \mathrm{M}\right)$. Similar criteria have been used by other investigators for identifying cerebellar granule cells in culture (Lasher and Zagon, 1972; Messer, 1977; Seil et al., 1979).

We have further characterized these cells using immunocytochemical staining. Since the presence of NSE immunoreactivity has been correlated with granule cell development in vivo (Marangos et al., 1980; Schmechel et al., 1980), we have attempted to distinguish between differentiated and undifferentiated granule cells (neuroblasts) in culture using NSE reactivity. Figure 2 shows a P4 explant after $5 \mathrm{~d}$ in vitro (DIV) that was fixed and stained for NSE. At this stage of development, the majority of granule cell bodies that had migrated away from the explant were NSE-positive, as were their long processes.

Figure 3 illustrates graphically that the percentage of cells showing immunocytochemical staining increased with distance from the explant. These results are indicative of the majority of explants examined, although individual cxplants showed somc variability in the actual pattern of staining (presumably due to differences in orientation and content of each explant). After 3 DIV, cells within $140 \mu \mathrm{m}$ of the explant were mostly NSE negative, and the majority beyond $140 \mu \mathrm{m}$ stained positively (shaded area in Fig. 3 represents the number of NSE-positive cells). Even at later stages ( 5 and 7 DIV), the percentage of positivestaining cells beyond $140 \mu \mathrm{m}$ was always higher than cells closer to the explant. After 1 week in culture, all cells further than 140 $\mu \mathrm{m}$ were NSE positive. At this stage, only cells adjacent to the explant $(<50 \mu \mathrm{m})$ remained NSE negative.

The intensity of NSE staining of migrating granule cells increased throughout the first few weeks and reached its maximum after 1 month. However, in serum-supplemented or defined medium containing normal potassium concentrations (ca. $5 \mathrm{~mm}$ ), the number of granule cells diminished drastically after 1-2 weeks. This trend can be seen in Figure 3, which shows that the number of cells beyond $140 \mu \mathrm{m}$ was less on day 9 than on day 7. By day 11 (not shown) the number of granule cells was severely reduced in most cultures. Cell loss was noticeably reduced when explants were cultured in media containing elevated potassium (25 mM). Under such conditions, many granule cells survived beyond 1 month (also see Lasher and Zagon, 1972; Thangnipon et al., 1983; Kingsbury et al., 1985). Cultures grown in elevated potassium (high $\mathrm{K}^{+}$) also exhibited accelerated NSE immunoreactivity, shifting the data shown in Figure 3 by 2-3 d.

Cultures prepared using late embryonic cerebella displayed each of the features described above for postnatal explants, but the development was delayed. For example, in cerebella cultured from E20 fetuses ( $2 \mathrm{~d}$ before birth), the onset of any NSE staining of granule cells occurred after about 1 week, as opposed to 2$3 \mathrm{~d}$ with P4 tissue (as in Fig. 3). This result suggests that the timing of the differentiation of granule cells in culture is regulated by an internal clock (also see Trenkner et al., 1984).

\section{Development of electrical excitability in cultured granule cells}

Intracellular recordings from granule cell bodies at the leading edge of the migration showed progressive changes during the first month in culture. During the first week, most cells were inexcitable, exhibited a large input resistance $\left(\sim 10^{4} \Omega \mathrm{cm}^{2}\right)$, and had resting potentials from -30 to $-35 \mathrm{mV}$. After 7-10 DIV, the input resistance decreased 10 -fold and resting potentials increased to approximately $-60 \mathrm{mV}$. Also, synaptic potentials and small, nonovershooting action potentials appeared at this time (Fig. $4, A, B$ ). Spontaneous action potentials were rare at 
A

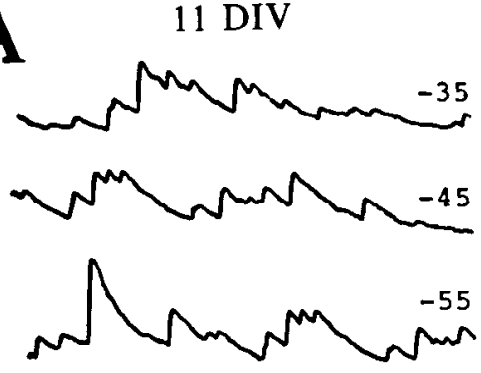

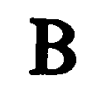

11 DIV

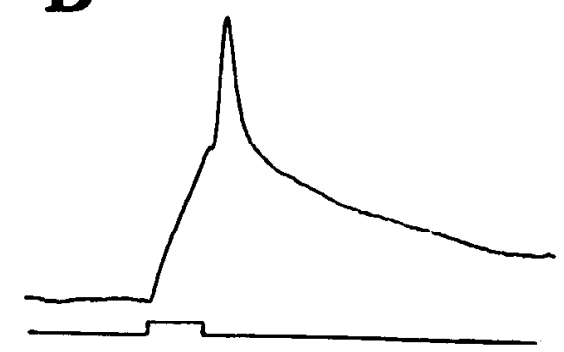

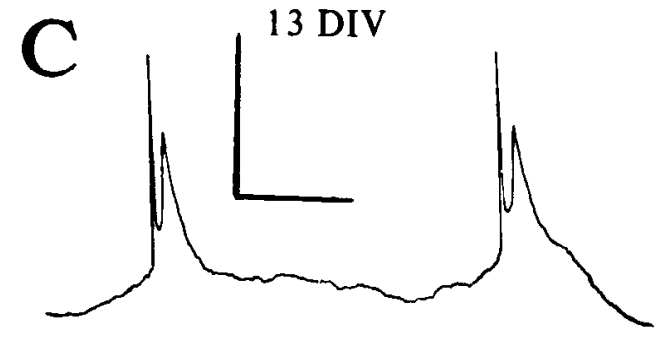

D

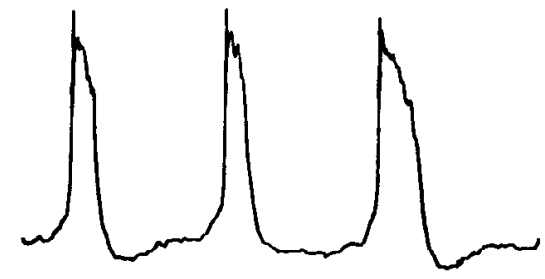

30 DIV
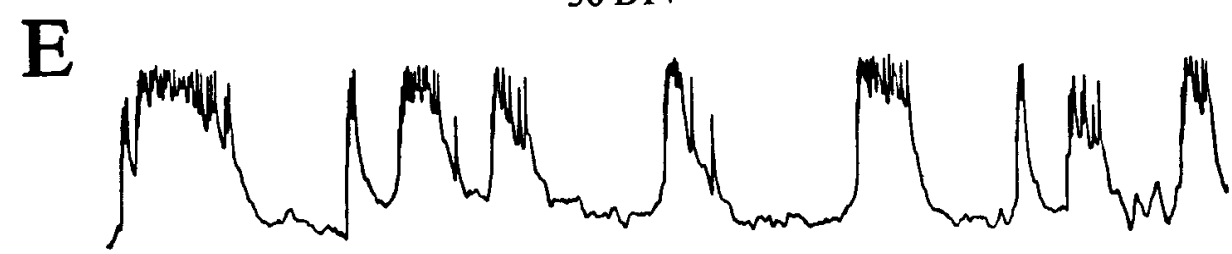

Figure 4. Progressive changes over time in electrical excitability were recorded from granule cells. After 11 days in vitro $(D I V)$, EPSPs $(A)$ and small action potentials $(B)$ could be recorded from most cells. Rhythmic firing patterns developed with longer times in culture $(C-E)$. The depolarizing phases of these firing patterns progressively lengthened and spike height decreased over time. Resting potentials were approximately $-60 \mathrm{mV}$ in all records except $A$, where it was changed, as indicated, under current clamp. Calibration bars: $30 \mathrm{mV}$ for all traces; $400 \mathrm{msec}$ $(A), 100 \mathrm{msec}(B), 200 \mathrm{msec}(C), 1 \mathrm{sec}$ $(D, E)$. this stage. By the end of the second week, spikes were overshooting $(0 \mathrm{mV})$ and were frequently seen as part of rhythmic firing patterns (Fig. 4C). Action potentials patterns included doublets in which the duration of the second spike lasted much longer than the first. During the third week in culture, the depolarizing phase of the rhythmic firing was very prolonged, sometimes lasting $0.5 \mathrm{sec}$ (Fig. $4 D$ ). After 1 month in culture, granulc cclls displayed complex patterns of bursting, and the depolarizing phases were even longer, approaching $1 \mathrm{sec}$ in duration (Fig. $4 E$ ).

\section{Development of voltage-dependent conductances in cultured granule cells}

Voltage-clamp analyses of membrane conductances were performed daily on migrating granule cells during the first 10 days in culture and periodically thereafter up to 1 month. In general, our results allowed us to subdivide granule cells into 4 types (neuroblasts, immature, intermediate, and mature cells) based primarily upon differences in the types of current profiles we recorded over time. Neuroblasts, which predominated during the first few days (Fig. 3), showed no sign of voltage-dependent conductances. Immature granule cells were predominant by the end of the first week and displayed small inward and outward currents. The amplitudes of these currents increased steadily during the following 2 weeks, and cells with currents sufficient to generate action potentials were labeled intermediate granule cells (e.g., Figs. 4,B-D). We have tentatively identified mature granule cells as those present after 1 month in culture in which only axonal currents were present. The latter were the type that usually displayed bursting with prolonged depolarizations and shortened spikes (e.g., Fig. 4E).

Immature granule cells displayed small outward currents first, but approximatly $80 \%$ of the cells had inward currents by the end of the first week. Figure 5 shows representative current records from a cell with only outward currents after 2 DIV. The currents were generated under voltage clamp using positive steps from 2 different holding potentials. A small voltage-dependent outward current was visible with steps from $-40 \mathrm{mV}$ to voltages above $0 \mathrm{mV}$ (Fig. 5A). This current increased in amplitude during the initial $10 \mathrm{msec}$ and remained constant for up to several hundred milliseconds (data not shown). This current is similar to the delayed potassium current $\left(I_{\mathrm{K}}\right)$ first described in squid axon (Hodgkin and Huxley, 1952a) and more recently described in mammalian neurons (for review, see Crill and Schwidt, 1983). Holding the membrane potential at $-80 \mathrm{mV}$ and stepping voltage positive demonstrated a small transient, voltage-dependent outward current in the same cell (Fig. $5 B$ ). This current activated quickly and declined substantially by 10 msec into the pulse. It was activated from holding potentials 


\section{DIV}

A

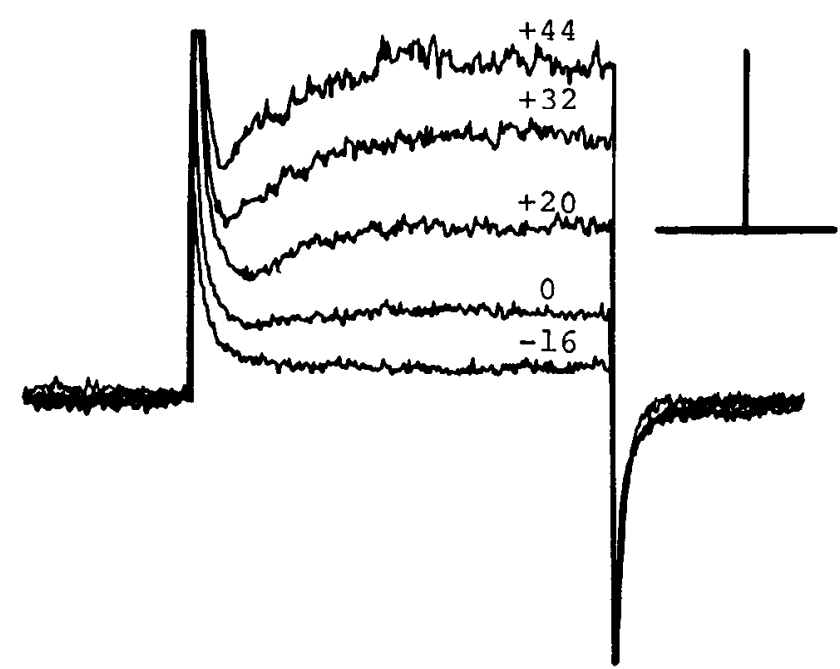

B

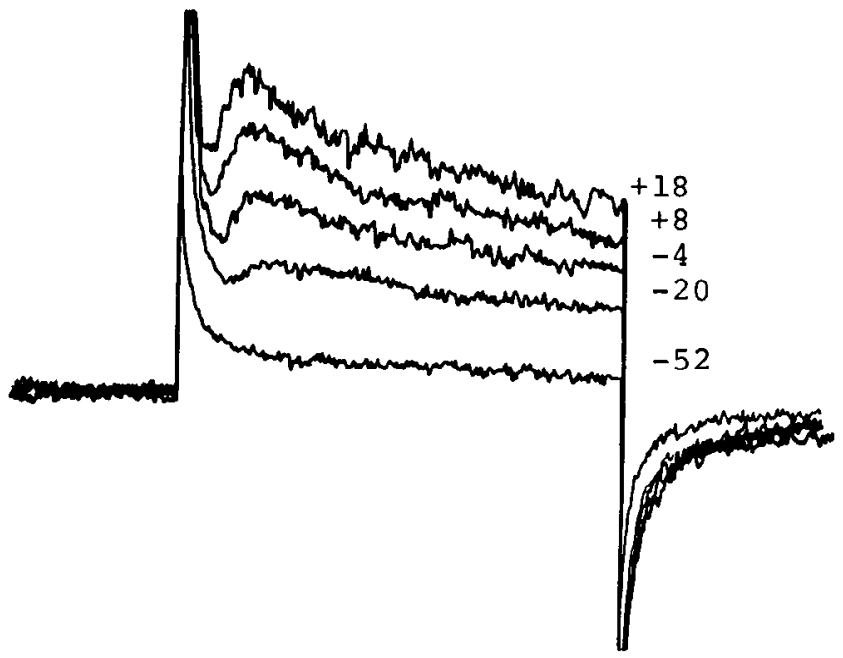

Figure 5. Current traces evoked from an immature granule cell under voltage clamp after 2 DIV. $A$, Holding potential was $-40 \mathrm{mV}$, and depolarizing voltage steps above $0 \mathrm{mV}$ activated small delayed outward currents. $B$, Transient outward currents were activated with steps above $-40 \mathrm{mV}$ from a holding potential of $-80 \mathrm{mV}$. Calibration bars $(A$ and $B), 60 \mathrm{pA}$ and $10 \mathrm{msec}$.

more negative than $-60 \mathrm{mV}$ and is similar to the transient potassium current $\left(I_{A}\right)$ characterized initially in gastropod neurons (Hagiwara et al., 1961; Connor and Stevens, 1971; Neher, 1971) and later in many neuronal and non-neuronal cells (see Rogawski, 1985).
By the end of the second week in culture, the current profiles of developing granule cells had changed considerably as inward and outward currents had increased 5- to 10-fold in amplitude. Figure 6 shows current records from an intermediate granule cell after 18 DIV obtained with the same protocols used for

\section{DIV}

A

B
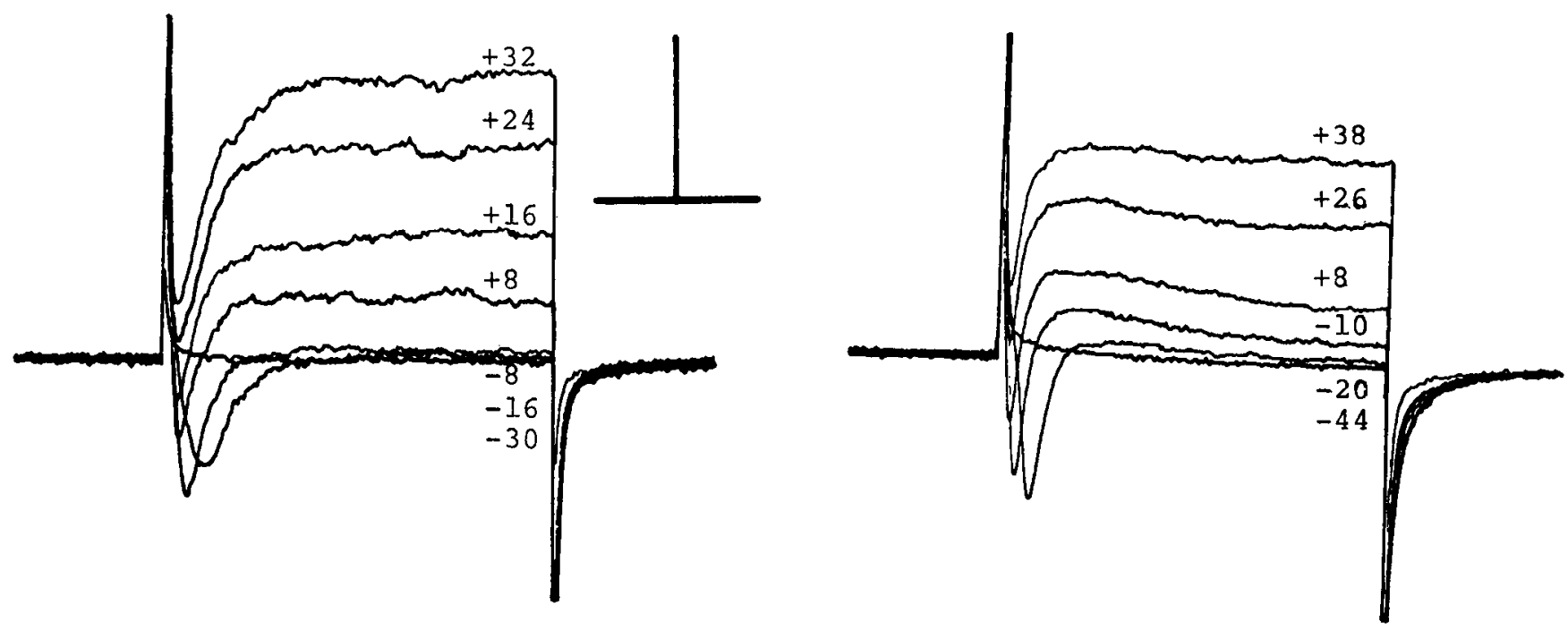

Figure 6. Current traces from an intermediate granule cell under voltage clamp after 18 DIV. Same protocols as in Figure 5. Calibration bars, $600 \mathrm{pA}$ and $10 \mathrm{msec}$. Inward currents were activated from either $-40 \mathrm{mV}(A)$ or $-80 \mathrm{mV}(B)$ with steps above $-30 \mathrm{mV}$, but they were overshadowed by outward currents when steps extended beyond $+20 \mathrm{mV}$. 


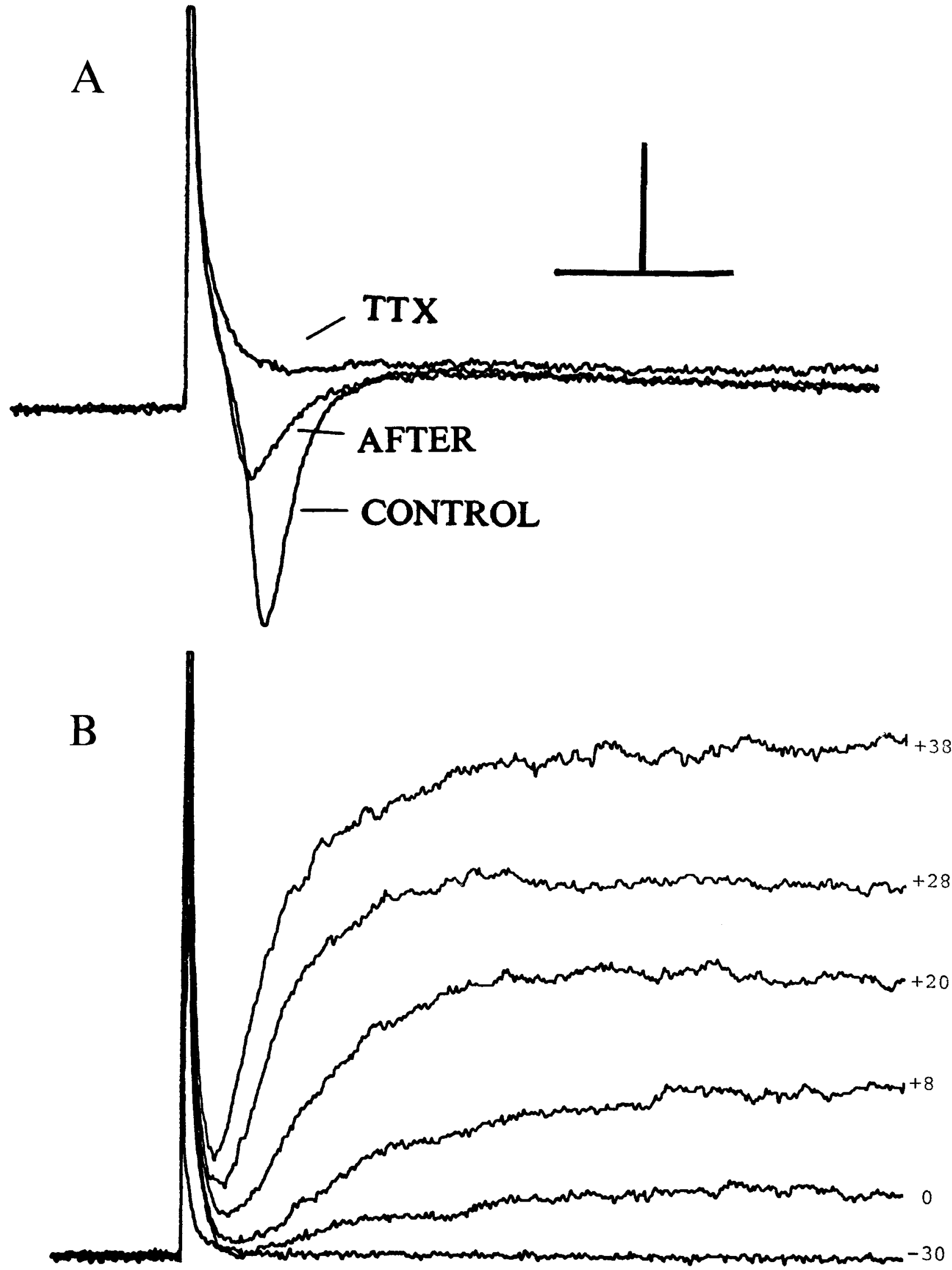

Figure 7. Currents recorded in the presence of TTX after 12 DIV. $A$, Inward current was evoked by stepping membrane voltage from -40 to $-28 \mathrm{mV}$ (CONTROL), which was completely blocked by $0.3 \mu \mathrm{M}$ TTX, an effect that was partially reversible after $10 \mathrm{~min}(A F T E R) . B$, Stepping voltage above $-30 \mathrm{mV}$ in the presence of TTX evoked the progressive activation of outward currents. Calibration bars $(A$ and $B), 300$ pA and 4 msec. 

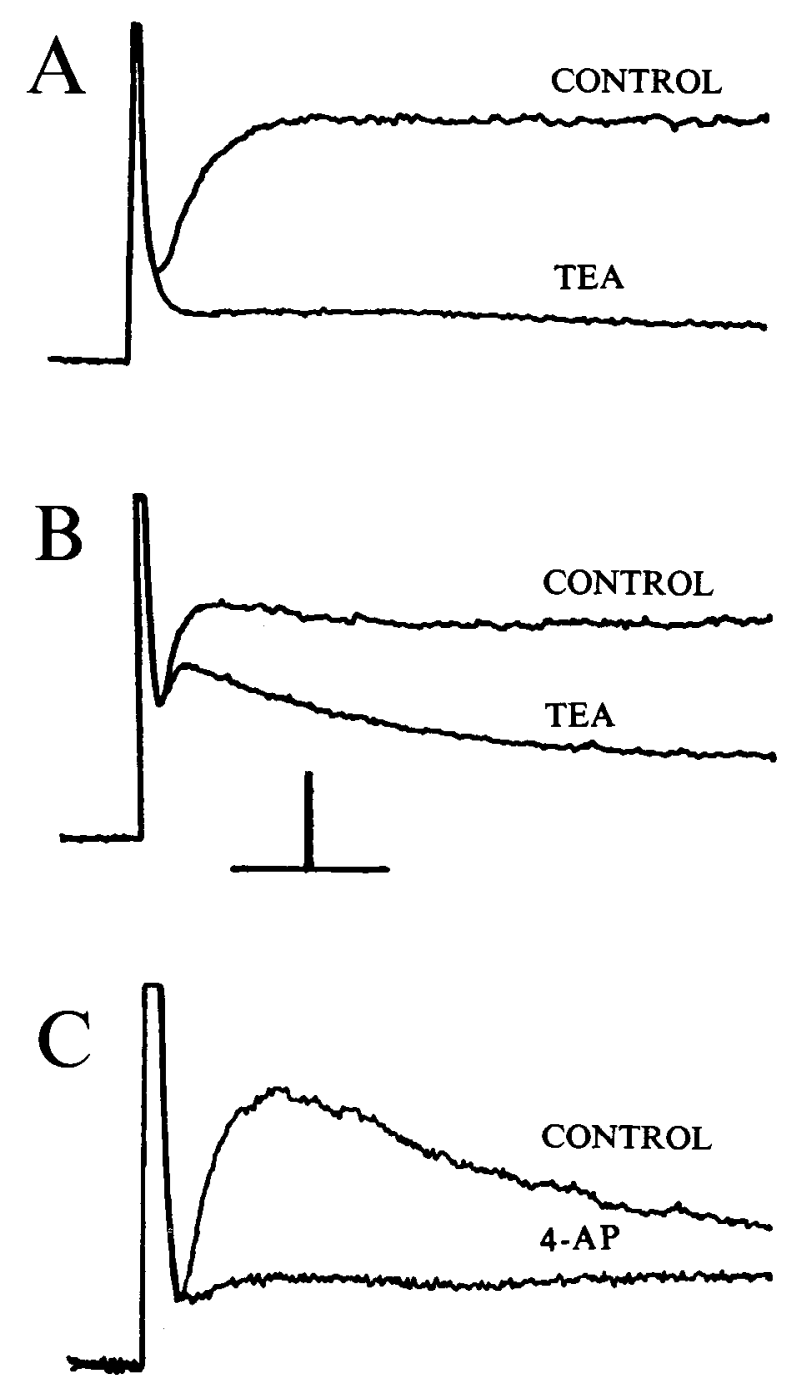

Figure 8. Outward currents from granule cells displayed different pharmacology as well as voltage dependence. $A$, Stepping membrane voltage from -40 to $+20 \mathrm{mV}$ in this developing granule cell (14 DIV) activated an outward current that was completely abolished after $15 \mathrm{~min}$ in $2 \mathrm{~mm}$ TEA. Inward current had "washed out" in the TEA trace. $B$, Same cell as in $A$ was used to show that TEA did not eliminate the transient outward current evoked by stepping voltage from -80 to $0 \mathrm{mV}$. Calibration bars $(A$ and $B), 500 \mathrm{pA}$ and $4 \mathrm{msec}$. $C$, Transient outward current was blocked in this immature granule cell ( $6 \mathrm{DIV})$ by $5 \mathrm{mM} \mathrm{4AP}$. The voltage step from -80 to $-10 \mathrm{mV}$ in 4AP demonstrated that inward current was absent and that the delayed outward current was not activated at $-10 \mathrm{mV}$. Calibration bars $(C), 50 \mathrm{pA}$ and $4 \mathrm{msec}$.

generating Figure 5 . The voltage steps from either -40 or -80 $\mathrm{mV}$ elicited transient inward currents at potentials above -20 $\mathrm{mV}$, while larger steps evoked overlapping inward and outward currents (Fig. 6, $A, B$ ).

The inward current could be selectively activated by stepping from -40 to $-10 \mathrm{mV}$, a region of membrane potential that did not activate the outward currents. Bath application of $0.3 \mu \mathrm{M}$ TTX blocked the inward current within minutes (Fig. $7 A$ ), an effect that was partially reversible if the drug was washed off immediately. The inward current was unaffected by the calcium channel blocker cadmium $\left(10^{-4} \mathrm{M} \mathrm{CdCl}_{2}\right)$, indicating that it was most likely an inward sodium current $\left(I_{\mathrm{Na}}\right)$. Like sodium currents in other preparations, its activation and inactivation time constants were voltage dependent. A more detailed kinetic anal- ysis was made impractical by the failure of the voltage clamp to obtain spatial homogeneity, which is illustrated in Figure $7 A$ by the shift in inward current during recovery from TTX (see Jakobsson et al., 1975).

In all cells tested there was a gradual "washout" of the inward current over the initial 15-30 min of recording. This loss of inward current was apparent even when evoked from a holding potential of $-80 \mathrm{mV}$, and it resulted in a compensatory increase in outward current. These effects occurred even in the presence of $10^{-3} \mathrm{M} 8$-bromo-cAMP in the bathing saline. We have not yet altered the patch electrode solution to attempt to prevent this washout.

The outward currents of intermediate granule cells were individually characterized in the presence of pharmacological agents for blocking overlapping currents. Analysis of the delayed outward current was performed while bathing cells in TTX (Fig. $7 B$ ) or after complete washout of the inward current. In either casc, the current was activated above $0 \mathrm{mV}$ with a time constant that was voltage-dependent, e.g., $\tau_{\text {act }}=2 \mathrm{msec}$ at $+38 \mathrm{mV}$. The time constant of activation of the current remained stable over the developmental phase when the amplitude continued to increase. The current activated in a sigmoidal fashion, best fit by an exponential function ( $n$ ) having a power of 4 (see Hodgkin and Huxley, 1952b). It was reduced by tetraethylammonium (TEA) ions at concentrations that did not affect the transient outward current (Fig. 8, $A, B$ ), and it was completely blocked by $10 \mathrm{~mm}$ TEA.

The transient outward current was completely blocked with $5 \mathrm{~mm}$ 4-aminopyridine (4AP) in intermediate cells (Fig. 8C). The kinetics of this current were analyzed in these cells in the presence of TTX plus TEA (Figs. 9, 10). In general, activation of the A-current took less than $1 \mathrm{msec}$ at $0 \mathrm{mV}$, and the inactivation time constant was approximately $25-30 \mathrm{msec}$ at $0 \mathrm{mV}$. The time course over which inactivation was removed at a negative potential was well fit by a single-exponential function from which a time constant (reactivation time constant) could be extracted. The reactivation time constant ranged from 25 to $50 \mathrm{msec}$ for the range -70 to $-100 \mathrm{mV}$. Comparison of kinetic parameters of this current in immature and intermediate granule cells indicated that there was no significant difference between groups of cells. The activation and inactivation curves are shown in Figure 10 for an immature cell (2 DIV), as well as for an intermediate cell bathed in TTX (33 DIV) or TTX plus TEA (17 DIV). As with the other currents, there was no significant change in the voltage dependence of the A-current with maturation.

We have not systematically analyzed the currents of cells cultured longer than 1 month. However, preliminary experiments on older cells grown in high-K medium have revealed 2 features that may be important for understanding the fully differentiated "mature" granule neuron. First, a small TTX-insensitive inward current activated between -60 and $-80 \mathrm{mV}$ was found in some cells. Cells with this current exhibited a small action potential with anode-break excitation in the presence of TTX. Second, about one-third of the older cells displayed no voltage-dependent somatic currents (Fig. 11 $\mathrm{A}$ ), even though GABA responses were present (see following paper). In some of these cells, voltage steps produced current deflections that appeared to be invading axonal currents (Fig. 11B). Axonal currents were characterized by latency and all-or-none activation. The shortened spikes often seen in recordings from mature cells (e.g., Fig. $4 E$ ) may have been due to axonal spikes invading 

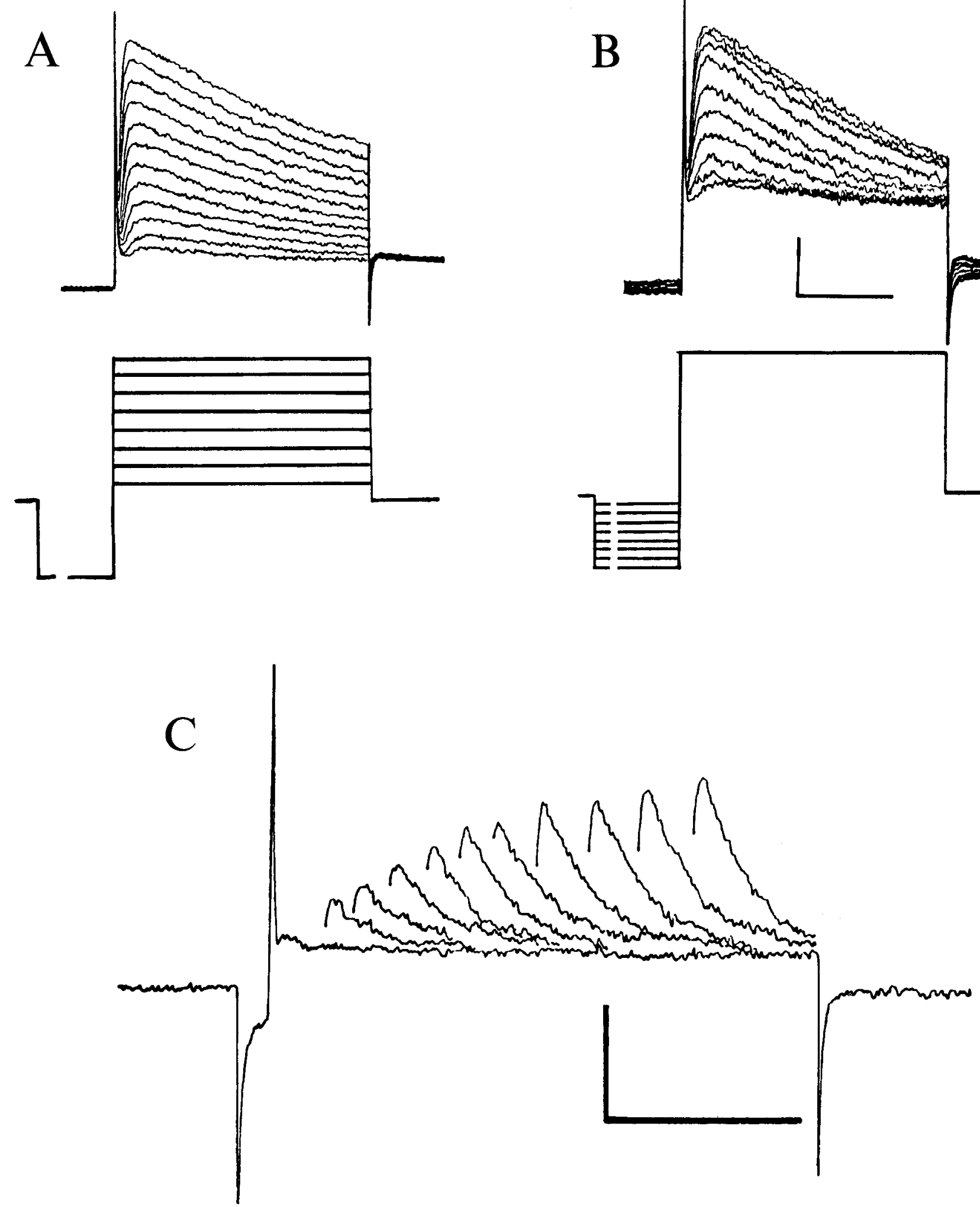

Figure 9. Voltage-clamp analysis of transient outward currents in a granule cell ( 33 DIV) bathed in $0.3 \mu \mathrm{M}$ TTX. $A$, Activation of the current was displayed following a 2 sec conditioning pulse from -40 to $-94 \mathrm{mV}$. Test pulses from -94 to $-40 \mathrm{mV}$ and above were performed in $5 \mathrm{mV}$ increments. These data were used to calculate an inactivation time constant of approximately $30 \mathrm{msec}$ for the transient outward current. $B$, Voltage dependence of inactivation was examined in the same cell used in $A$. Conditioning steps $(2 \mathrm{sec})$ from -40 to $-80 \mathrm{mV}$ in $4 \mathrm{mV}$ increments were followed by a standard test pulse to $-5 \mathrm{mV}$. Calibration bars $(A$ and $B), 200 \mathrm{pA}$ and $10 \mathrm{msec}$. $C$, Reactivation time for the transient outward current was analyzed using a conditioning step to $-80 \mathrm{mV}$ for various lengths of time followed by a test step to $-15 \mathrm{mV}$. Here, the current records from 11 such runs on a granule cell (6 DIV) have been superimposed on the same figure, and the reactivation time was 30 msec. Calibration bars, $250 \mathrm{pA}$ and $40 \mathrm{msec}$. 


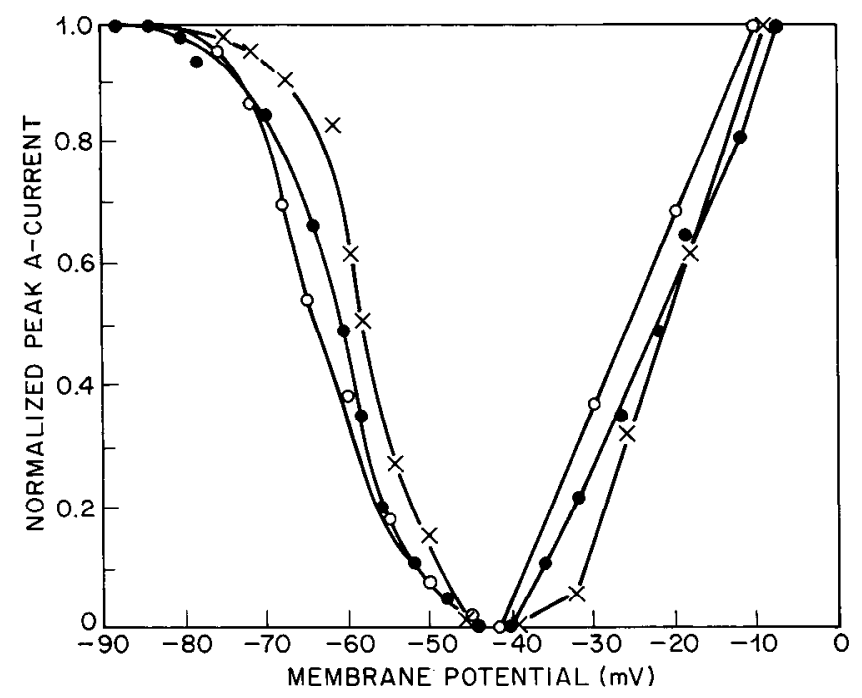

Figure 10. Activation and inactivation curves were plotted using data similar to that shown in Figure 9, $A$ and $B$, obtained from an immature granule cell (2 DIV) $(x)$ and from intermediate cells in TTX $(\bullet)$ and TTX plus TEA $(O)$. There is a slight shift to the left in the $I-V$ curves between immature and intermediate granule cells, an effect that was within the range of cellular variability.

an otherwise inexcitable soma. It would appear that ionic conductances were present in mature cells but were generated in regions distant from the soma.

\section{Discussion}

Our results indicate that several stages of granule cell differentiation can be studied using postnatal explant cultures. Moreover, we have identified 4 developmental stages (neuroblast, immature, intermediate, and mature) that these cells pass through during differentiation. These stages were characterized by differences in cell location from the explant, intensity of NSE staining, excitability, and the magnitude of several voltage-dependent conductances. Although it is not yet possible to perform voltage-clamp measurements from granule cells in vivo because of their small size and inaccessibility, we believe that similar stages in granule cell development may occur in situ.

Granule cell neuroblasts were characterized as small, round NSE-negative cells with 2 or 3 long processes. These cells proliferated in culture and were found most often adjacent to the host tissue. Neuroblasts were inexcitable and displayed only leakage currents under voltage clamp. We suggest that these cells may be representative of those found within the external germinal layer in vivo. Developing granule cells in this layer, as well as the cultured cells, extend processes while continuing to divide and have therefore been referred to as bi- or tripolar neuroblasts (Ramon y Cajal, 1911; Del Cerro and Snider, 1972).

Between postnatal days 5-20 in vivo, the nuclei of the granule cell neuroblasts migrate down the vertical processes and settle beneath the Purkinje cell layer. This nuclear relocation gives rise to the formation of the (internal) granular cell layer (Addison, 1911; Altman, 1972b, 1982). During this migration period in vivo, the granule cells begin to express NSE immunoreactivity (Schmechel et al., 1978, 1980). In early postnatal cultures we classified small, round NSE-positive cells with small voltage-dependent conductances as immature granule cells. These cells were most prevalent after 1 week in culture and were found up to $500 \mu \mathrm{m}$ from the host tissue. We believe that immature granule cells in vitro may have properties similar to granule cells in vivo undergoing nuclear migration to the granule cell layer.

After 2 weeks in culture the intensity of NSE immunoreactivity increased in granule cells, similar to results in vivo (Marangos et al., 1980). During this time the voltage-dependent conductances progressively increased in amplitude. Granule cells with conductances sufficient to generate action potentials were classified as intermediate cells. Electrophysiological evidence for granule cell excitability in vivo occurs about this time and is based upon synaptic transmission between granule cells and Purkinje cells (Shimono et al., 1976). The results presented here suggest that the timing of this differentiation process in vitro is similar to events in vivo.

Granule cells cultured longer than 1 month often displayed only axonal currents, indicating that channels on the soma had either translocated or were no longer activatable. Extracellular single-unit recordings from the granular cell layer of adult cats (Eccles et al., 1966) and turtles (Walsh et al., 1974) have been reported. However, these recordings were believed to have resulted from activity in mossy fiber terminals, since antidromic activation of parallel fibers did not evoke spiking within the granular cell layer. Thus, there is evidence that adult granule cell somata are inexcitable in higher vertebrates, although in lower vertebrates the somata may retain excitability (see, for example, Eccles et al., 1970). We have therefore classified cultured granule cells displaying only axonal currents as mature cells.

Under voltage clamp both inward and outward currents were recorded from developing granule cells. The inward current was probably mediated by an increase in sodium ion conductance, since the calcium channel blocker cadmium had no apparent effect on the current. Although no calcium currents were detected with whole-cell recording, our results in the following paper demonstrate that calcium currents did develop in the cultured granule cells (Connor et al., 1987). Apparently the calcium currents were either too small to record or were rapidly washed out during whole-cell recording (cf. Fedulova et al., 1981; Byerly and Hagiwara, 1982; Fenwick et al., 1982b).

The TTX-sensitive current was more slowly washed out, suggesting that it, too, may be regulated by some solublc cofactor. In this regard, cAMP-dependent phosphorylation of the sodium channel from rat brain has been reported (Costa and Catterall, 1984). However, we observed no stabilizing effect on the current in the presence of the cAMP analog 8-bromo-cAMP. The possibility of a dialysis-induced shift in the voltage dependence of inactivation of the current cannot be ruled out presently. A negative shift in the voltage-dependence of activation, as has been reported with whole-cell recording in other cells (cf. Fernandez et al., 1984), would not explain our results.

Two types of outward currents developed in cultured granule cells. A delayed TEA-sensitive outward current was activated above $0 \mathrm{mV}$ with kinetics similar to the delayed-rectifier potassium current in spinal motoneurons (Barrett et al., 1980) and sympathetic ganglion cells (Adams et al., 1982). A transient 4AP-sensitive outward current was activated below $-60 \mathrm{mV}$ and displayed kinetic properties similar to the potassium Acurrent found in various vertebrate neurons (Adams et al., 1982; Gustafson et al., 1982; Segal et al., 1984; Zbicz and Weight, 1985 ) but with much faster activation and inactivation than its counterpart in invertebrate neurons (Connor and Stevens, 1971; 


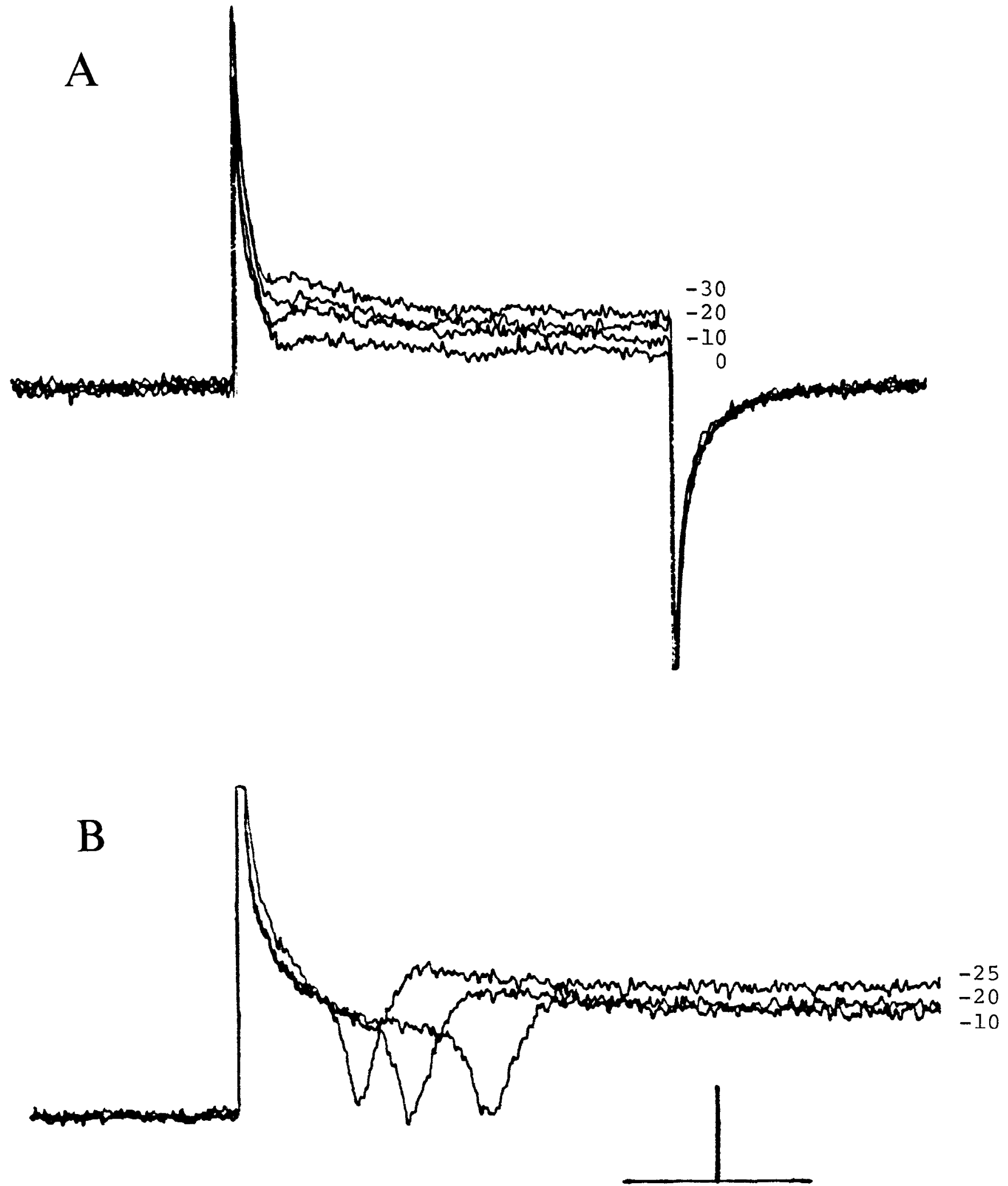

Figure 11. Currents generated under voltage clamp from granule cells older than 1 month (36 DIV) in culture. $A$, This cell was heid at $-80 \mathrm{mV}$ and voltage was stepped to various potentials immediately after penetration. Unlike intermediate granule cells, no obvious voltage-dependent conductances were present (cf. Fig. 6). Calibration bars, $200 \mathrm{pA}$ and $10 \mathrm{msec}$. $B$, Another mature granule also lacked somatic currents, and all-ornone axonal currents were activated with voltage steps from $-80 \mathrm{mV}$. Calibration bars, $200 \mathrm{pA}$ and $4 \mathrm{msec}$. 
Neher, 1971). The kinetic properties of both outward currents remained unchanged over the period when the currents increased in amplitude.

The development of each of the membrane currents in granule cells showed a progressive increase in amplitude during the first 2 to 3 weeks in culture. This was also the case for the calcium current, which is described in the following article (Connor et al., 1987). We did not find any change in the ionic dependence of the action potential during development, a change that has been reported for some vertebrate neurons (Spitzer, 1981). Our evidence that the action potential in the cell body develops and then disappears with further maturation (although remaining on the processes) does suggest that ion channels are modified during development. Whether the channels become unresponsive or actually translocate down the processes remains to be seen. Evidence presented in the following paper argues that the soma glutamate response also disappears during maturation. Although we could not easily test whether the processes exhibited glutamate receptors - because of their small size and, therefore, poor electronic conduction properties - the results are consistent with the observation that glutamate receptors on mature granule cells in vivo are on the parallel fibers.

We have not been able to make any clear assessment of the radial-glial hypothesis (Rakic, 1971, 1981) in culture. This hypothesis suggests that the "interaction of radially-positioned glial cells (e.g., Bergmann cells in the cerebellum) and immature neurons may play a crucial role in the orientation, displacement and positioning of neurons within the cerebral and cerebellar cortices." In the cerebellum this interaction must begin with the descending vertical processes of granule cell neuroblasts. Granule cell processes in culture were very thin and difficult to resolve without staining. Immunocytochemical staining of explant cultures for GFAP and NSE did show that both glial and neuronal processes radiated from the explants. However, we were unable to determine which, if either, of the processes was guiding the orientation.

We have made several observations on cultured cells that provide indirect evidence for the radial-glial hypothesis. (1) Using embryonic explants we found that GFAP-positive fibers appeared several days before NSE-positive fibers. (2) Radiating GFAP-positive processes typically extended no more than 500 $\mu \mathrm{m}$ from the explant, a distance beyond which granule cell somata were rarely found. (3) Granulc cell somata wcre sometimes clearly attached to radiating fiber bundles containing processes that were positive for both GFAP and NSE. Time-lapse recordings by Trenkner et al. (1984) have shown that granule cell somata can move along these fiber bundles. Taken together these observations using cultured cells lend support to the radial-glial hypothesis.

The issue as to whether tissue culturing can be used to probe normal cell functioning must be resolved for each cell type under each specified culture condition. In the culture system we employed, cells were kept viable under conditions that resembled developing cerebellum in several important ways. In spite of the absence of a Purkinje cell layer and climbing fiber and mossy fiber inputs, the granule cells displayed differentiated properties that developed over a time period consistent with events in vivo. We believe our culture conditions may afford the opportunity to examine the "normal" development of granule cells under conditions that allow for cellular analyses not currently possible in vivo.

\section{References}

Adams, P., D. Brown, and A. Constanti (1982) M-currents and other potassium currents in bullfrog sympathetic neurons. J. Physiol. (Lond.) 330: $537-572$.

Addison, W. (1911) The development of the Purkinje cells and of the cortical layers in the cerebellum of the albino rat. J. Comp. Neurol. v. $21,459-487$.

Ahmed, Z., P. Walker, and R. Fellows (1983) Properties of neurons from dissociated fetal rat brain in serum-free culture. J. Neurosci. 3: 2448-2462.

Altman, J. (1972a) Postnatal development of the cerebellar cortex in the rat. I. The external germinal layer and the transitional molecular layer. J. Comp. Neurol. 145: 353-398.

Altman, J. (1972b) Postnatal development of the cerebellar cortex in the rat. II. Maturation of the components of the granular layer. J. Comp. Neurol. 145: 465-514.

Altman, J. (1982) Morphological development of the rat cerebellum and some of its mechanisms. Exp. Brain Res. 6(suppl.): 8-46.

Barrett, E., J. Barrett, and W. Crill (1980) Voltage-sensitive outward currents in cat motoneurones. J. Physiol. (Lond.) 304: 251-276.

Bignami, A., and D. Dahl (1973) Differentiation of astrocytes in the cerebellar cortex and the pyranudal tracts of the newborn rat. An immunofluorescence study with antibodies to a protein specific to astrocytes. Brain Res. 49: 393-402.

Bignami, A., and D. Dahl (1974) Astrocyte-specific protein and neuroglial differentiation. An immunofluorescence study with antibodies to the glial fibrillary acidic protein. J. Comp. Neurol. 153: 27-38.

Byerly, L., and S. Hagiwara (1982) Calcium currents in internally perfused nerve cell bodies of Limnea stagnalis. J. Physiol. (Lond.) 322: 503-523

Connor, J. A., and C. F. Stevens (1971) Voltage clamp studies of a transient outward membrane current in gastropod neural somata. $J$. Physiol. (Lond.) 213: 21-30.

Connor, J. A., H. Tseng, and P. Hockberger (1987) Depolarizationand transmitter-induced changes in intracellular $\mathrm{Ca}^{2+}$ of rat cerebellar granule cells in explant cultures. J. Neurosci. 7: 1384-1400.

Costa, M., and W. Catterall (1984) Cyclic AMP dependent phosphorylation of the $\alpha$ subunit of the sodium channel in synaptic nerve ending particles. J. Biol. Chem. 259: 8210-8218.

Crill, W., and P. Schwidt (1983) Active currents in mammalian central neurons. Trends Neurosci. 6: 236-240.

Cull-Candy, S., and D. Ogden (1985) Ion channels activated by L-glutamate and GABA in cultured cerebellar neurons of the rat. Proc. $R$. Soc. London [Biol.] 224: 367-373.

DeBlas, A. (1984) Monoclonal antibodies to specific astroglial and neuronal antigens reveal the cytoarchitecture of the Bergmann glial fibers in the cerebellum. J. Neurosci. 4: 265-273.

Del Cerro, M., and R. Snider (1972) Studies on the developing cerebellum. II. The ultrastructure of the external granular layer. J. Comp. Neurol. 144: 131-164.

Drejer, J., O. Larsson, and A. Schousboe (1983) Characterization of uptake and release processes for D- and L-aspartate in primary cultures of astrocytes and cerebellar granule cells. Neurochem. Res. 8: 231-243.

Eccles, J., R. Llinás, and K. Sasaki (1966) The excitatory synaptic action of climbing fibres on the Purkinje cells of the cerebellum. J. Physiol. (Lond.) 182: 268-296.

Eccles, J., H. Taborikova, and N. Tsukahara (1970) Responses of the granule cells of the selachian cerebellum (Musteles canis). Brain Res. 17: 87-102.

Fedulova, S., P. Kostyuk, and N. Veselovskii (1981) Calcium channels in the somatic membrane of the rat dorsal root ganglion neurons, effect of cAMP. Brain Res. 214: 210-214.

Fenwick, E., A. Marty, and E. Neher (1982a) A patch-clamp study of bovine chromaffin cells and of their sensitivity to acetylcholine. $J$. Physiol. (Lond.) 331: 577-597.

Fenwick, E., A. Marty, and E. Neher (1982b) Sodium and calcium channels in bovine chromaffin celis. J. Physiol. (Lond.) 331: 599635.

Fernandez, J., A. Fox, and S. Krasne (1984) Membrane patches and whole-cell membranes: A comparison of electrical properties in rat clonal (GH3) cells. J. Physiol. (Lond.) 356: 563-585.

Fischer, G. (1982) Cultivation of mouse cerebellar cells in serum-free, 
hormonally defined media: Survival of neurons. Neurosci. Lett. 28 : 325-329.

Gustafson, B., M. Galvan, P. Grafe, and H. Wigstrom (1982) A transient outward current in a mammalian central neurone blocked by 4-aminopyridine. Nature 299: 252-254.

Hagiwara, S., K. Kusano, and N. Saito (1961) Membrane changes of Onchidium nerve cell in potassium-rich media. J. Physiol. (Lond.) 155: 470-489.

Hamill, D., A. Marty, E. Neher, B. Sakmann, and F. Sigworth (1981) Improved patch-clamp techniques for high-resolution current rccording from cells and cell-free membrane patches. Pfluegers Arch. 391: 85-100.

Hockberger, P., and J. A. Connor (1985) Properties of cultured cerebellar granule cells measured with whole-cell patch recording and imaging of $\mathrm{Ca}^{2+}$ indicator fluorescence. Soc. Neurosci. Abstr. 11: 508.

Hockberger, P., H. Tseng, and J. A. Connor (1986) Immunocytochemical and electrophysiological correlates of developing mammalian cerebellar neurons in vitro. Soc. Neurosci. Abstr. 12:852.

Hodgkin, A., and A. Huxley (1952a) Currents carried by sodium and potassium ions through the membrane of the giant axon of Loligo. J. Physiol. (I ond.) 116: 449-472.

Hodgkin, A., and A. Huxley (1952b) A quantitative description of membrane current and its application to conduction and excitation in nerve. J. Physiol. (Lond.) 117: 500-544.

Ito, M. (1984) The Cerebellum and Neural Control, Raven, New York. Jakobsson, E., L. Barr, and J. A. Connor (1975) An equivalent circuit for small atrial trabeculae of frog. Biophys. J. 15: 1069-1085.

Kingsbury, A., V. Gallo, P. Woodhams, and R. Balazs (1985) Survival, morphology and adhesion properties of cerebellar interneurones cultured in chemically defined and serum-supplemented medium. Dev. Brain Res. 17: 17-25.

Lasher, R., and I. Zagon (1972) The effect of potassium on neuronal differentiation in cultures of dissociated newborn rat cerebellum. Brain Res. 41: 482-488.

I evi, G., F. Aloisi, M. Ciotti, and V. Gallo (1984) Autoradiographic localization and depolarization-induced release of acidic amino acids in differentiating cerebellar granule cell cultures. Brain Res. 290: 7786.

Marangos, P., D. Schmechel, A. Parma, and F. Goodwin (1980) Developmental profile of neuron-specific (NSE) and non-neuronal (NNE) enolase. Brain Res. 190: 185-193.

Messer, A. (1977) The maintenance and identification of mouse cerebellar granule cells in monolayer culture. Brain Res. 130: 1-12.

Messer, A. (1978) Abnormal staggerer cerebellar cell interactions and survival in vitro. Neurosci. Lett. 9: 185-188.

Messer, A., and D. Smith (1977) In vitro behavior of granule cells from agranular neurological mutants of mice. Brain Res. 130: 13-23.

Messer, A., J. Mazurkiewicz, and P. Maskin (1981) Growth of dissociated rat cerebellar cells using serum-free supplemented media and varied transferring concentrations. Cell. Mol. Neurobiol. 1: 99-114.

Neher, E. (1971) Two fast transient current components during voltage clamp on snail neurones. J. Gen. Physiol. 58: 36-53.

Rakic, P. (1971) Neuron-glia relationship during granule cell migra- tion in developing cerebellar cortex: A golgic and electronmicroscopic study in Maccacus rhesus. J. Comp. Neurol. 141: 283-312.

Rakic, P. (1981) Neuronal-glial interaction during brain development. Trends Neurosci. 7: 184-187.

Ramon y Cajal, S. (1911) Histologie du Systeme Nerveux de l'Homme et des Vertebrés, Maloine, Paris. [Reprinted by Consejo Superior de Investigaciones Cientificas, Madrid, 1972.]

Rogawski, M. (1985) The A-current: How ubiquitous a feature of excitable cells is it? Trends Neurosci. 8: 214-219.

Romijn, H., A. Habets, M. Mud, and P. Walters (1982) Nerve outgrowth, synaptogenesis and bioelectric activity in fetal rat cerebral cortex tissue cultured in serum-free, chemically defined medium. Dev. Brain Res. 2: 583-589.

Schmechel, D., P. Marangos, A. Zis, M. Brightman, and F. Goodwin (1978) Brain enolases as specific markers of neuronal and glial cells. Science 199: 313-315.

Schmechel, D., M. Brightman, and P. Marangos (1980) Neurons switch from non-neuronal enolase to neuron-specific enolase during differentiation. Brain Res. 190: 195-214.

Segal, M., M. Rogawski, and J. Barker (1984) A transient potassium conductance regulates the excitability of cultured hippocampal and spinal neurons. J. Neurosci. 4: 604-609.

Seil, F., N. Blank, and A. Leiman (1979) Toxic effects of kainic acid on mouse cercbellum in tissuc culture. Brain Res. 161: 253-265.

Seil, F., A. Leiman, and W. Woodward (1980) Cytosine arabinoside effects on developing cerebellum in tissue culture. Brain Res. 186: 393-408.

Shimono, T., S. Nosaka, and K. Sasaki (1976) Electrophysiological study on the postnatal development of neuronal mechanisms in the rat cerebellar cortex. Brain Res. 108: 279-294.

Spitzer, N. (1981) Development of membrane properties in vertebrates. Trends Neurosci. 4: 169-172.

Thangnipon, W., A. Kingsbury, M. Webb, and R. Balazs (1983) Observations on rat cerebellar cells in vitro: Influence of substratum, potassium concentration and relationship between neurons and astrocytes. Dev. Brain Res. 11: 177-189.

Trenkner, E., D. Smith, and N. Segil (1984) Is cerebellar granule cell migration regulated by an internal clock? J. Neurosci. 4: 2850-2855.

Walsh, J., J. Houk, and E. Mugnaini (1974) Identification of unitary potentials in turtle cerebellum and correlations with structures in granular layer. J. Neurophysiol. 37: 30-47.

Willinger, M., and D. Margolis (1985) Effect of the weaver (wv) mutation on cerebellar neuron differentiation. I. Qualitative observations of neuron behavior in culture. Dev. Biol. 107: 156-172.

Wroblewski, J., F. Nicoletti, and E. Costa (1985) Different coupling of excitatory amino acid receptors with $\mathrm{Ca}^{2+}$ channels in primary cultures of cerebellar granule cells. Neuropharmacology 24:919-921.

$\mathrm{Xu}, \mathrm{J}$. , and J. Wojcik (1985) GABA B receptor-mediated inhibition of AMP content in primary cultures of cerebellar granule cells. Soc. Neurosci. Abstr. 11: 1121.

Zbicz, K., and F. Weight (1985) Transient voltage and calcium-dependent outward currents in hippocampal CA3 pyramidal neurons. J. Neurophysiol. 53: 1038-1058. 